\section{DOJEMANJE MATERINSTVA IN STARŠEVSTVA SKOZI ČAS - PRELIMINARNA ŠTUDIJA}

\section{POVZETEK}

Prispevek prinaša teoretični pregled in analizo obstoječega razumevanja koncepta materinstva in z njim povezanih dejstev ter rezultate raziskave na podlagi za ta namen oblikovanega in uporabljenega vprašalnika. Avtorici v uvodnem delu predstavita teoretični pregled dojemanja in doživljanja ženskosti in materinstva skozi zgodovino in čas, kako se materinstvo vrednoti danes ter kakšne so napovedi za prihodnost. V empiričnem delu je raziskano, kakšne so trenutne predstave študentov in študentk o materinstvu, kakšna je njihova ocena o trenutnem položaju in vlogi žensk in mater v povezavi z materinskim mitom in tradicionalno vlogo matere in očeta ter kakšne so glede tega napovedi za prihodnost. Raziskava je bila opravljena v letu 2012, vanjo je bilo vključenih 100 rednih študentov in študentk, od tega 50 moških (50 odstotkov) in 50 žensk (50 odstotkov) s štirih fakultet Univerze v Ljubljani.

Statistično pomembna razlika se je pokazala na področju delitve vlog v družini in na področju pogleda na materinstvo in žensko v prihodnosti (največ študentov (60,0 odstotka) ocenjuje, da se bodo matere v prihodnosti bolj posvečale karieri in manj drǔ̌ini, medtem ko je takšne ga mnenja pomembno manj študentk (38,0 odstotka)). Posebej poudarjeno je dejstvo, da se študenti in študentke zavedajo sprememb, ki se pojavljajo skozi čas, čeprav rezultati še vedno kažejo prevladujoč tradicionalni pogled na materinstvo in vloge v družini. Rezultati kažejo, da se udeleženci raziskave zavedajo potrebe po enakosti spolov ter po enakovredni razdelitvi družinskih vlog med moškimi in ženskami. Naša raziskava je pokazala, da se tega bolj zavedajo ženske kot moški.

Ključne besede: rojstvo, vloge v družini, materinstvo, partnerstvo

\section{UNDERSTANDING OF MOTHERHOOD AND PARENTHOOD OVER TIME - PRELIMINARY STUDY - ABSTRACT}

The paper presents a theoretical overview and analysis of the current understanding of the concept of motherhood and related facts. Besides, it presents the results of a research obtained through a questionnaire designed and administered for this purpose. A theoretical overview of the perception and experience of femininity and motherhood in history is given in the introduction. Further, the role of motherhood and parenting is defined and an attempt is made to understand in what direction motherhood will develop in the future. The empirical part shows the ideas of young people (students) on motherhood, their opinion on the current situation and the role of women and mothers in relation to the maternal myth.

The survey, conducted in 2012, included 100 full-time students $(N=100), 50$ male $(50 \%)$ and 50 female $(50 \%)$, from four faculties of the University of Ljubljana. Statistically significant differences have been found in their views on the future of maternity. Most male students (60.0\%) believe that in the future mothers will be more focused on their careers and less on their families, whereas fewer female students share this view (38.0\%). The survey made it evident that young people are aware of the changes occurring over time, although the traditional view of the role of motherhood and the family is still predominant. The results also show that the respondents are aware of the need for gender equality and equal division of family roles between men and women. Our research revealed that women are more aware of this than men.

Keywords: birth, the role of family, motherhood, partnership

UDK : 316.36
Asist. Anita Jug

Došler

Asist. Metka Skubic

Zdravstvena

fakulteta

Univerze $v$ Ljubljani 


\section{POGLED NA MATERINSTVO IN ŽENSKE V PRETEKLOSTI}

Filozofi, politiki in zgodovinarji klasičnega obdobja so žensko kot idealno opisovali takrat, ko je tiha, nevidna in neopazna. Ženske so imele svojo družbeno identiteto le kot zakonite žene državljanov, medtem ko same po sebi niso bile državljanke, tako da se niso smele udeleževati političnega oz. javnega življenja ter niso opravljale javnih služb. Menili so, da ženska ne more odgovarjati za svoja dejanja in da ni zmožna opredeliti svojih interesov. Ženski pravni položaj je bil torej podrejen moškemu. Na ženske se je gledalo kot na bitja, ki jih je treba zaščititi, nadzirati in jih upravljati. Veljalo je prepričanje, da so ženske bitja nestabilnega nerazumljivega značaja, osebe, ki niso zmožne racionalne presoje in odločanja - v nasprotju z moškimi. Kasneje so filozofi temu rekli, da so nesvobodne. Ženska si tudi svojega moža ni izbrala sama, ampak ga je zanjo poiskal njen varuh oz. njena družina. Neporočena ženska je bila obsojena na revščino ali prostitucijo, saj ni bilo legalnih možnosti in načinov, da bi bila ženska ekonomsko samostojna in neodvisna. Antični pisci so žensko manjvrednost utemeljevali predvsem biološko. Temelj atenske moralnosti sta bila spoštovanje in zvestoba družini. Atenske ženske so bile omejene na družinsko življenje, ki ga zaznamujejo skritost, zasebnost in predvsem zaprtost. Poroka in materinstvo sta veljali za izpolnitev poslanstva ženske. Prepričani so bili, da je oseba ženskega spola rojena za to, da se poroči in rodi zakonite naslednike (Kristan, 2005).

Ker so ženske veljale za nesposobne upravljati same sebe, so morale biti pod nadzorom in oblastjo moškega skrbnika, ki naj bi jim s svojo racionalnostjo priskrbel to, kar jim »po naravi« manjka, torej samonadzora in racionalnosti. Poroka je tako bila tisti legalni akt, ki je moškemu dal pooblastilo za to institucijo. Mož je imel pravico in dolžnost upravljati ženino življenje - pred poroko je za to običajno skrbel njen oče. Poroka je dekle udomačila, kar se je še bolj utrdilo takrat, ko je postala tudi mati. Vloga ženske kot matere in žene je bila tako rezultat njenega ujetja $\mathrm{v}$ družbeno kodificirane in afirmirane načine moškega nadzora nad njimi (Kristan, 2005).

\section{MATERINSTVO IN STARŠEVSTVO KOT POMEMBNI VLOGI V ZGODNII ODRASLOSTI}

V socioloških in humanističnih konceptih je zelo razširjena teza, da ima porod izjemen, temeljni vpliv na življenje ženske, njenih otrok in družine (Kent, 2003). Iz tega lahko sklepamo, da postati mati pomeni za slabo diferencirano žensko stres in strah, da bo izgubila lastno identiteto. Vloga matere se je skozi čas in prostor močno spremenila. Mit o materinstvu obsega tri splošno sprejete trditve: da otrok potrebuje mater, da mati potrebuje otroka in da je materinstvo največ, kar lahko ženska doseže v svojem življenju (Oakley, 2000). Brezmejna nežnost, neskončna zaščita, neizmerna skrb - vse to so lastnosti, ki jih imamo za samoumevne, ko razmišljamo o materinstvu. Glavna naloga »dobre matere« je izkazovanje neizmerne skrbi svojim otrokom. Mit o materinstvu predvideva, da se mati neomejeno razdaja za otroke (Wolf, 2001). Ključna pri tem mitu sta naturalizacija družbenega in podružbljanje naravnega. Mit se sklicuje na materinski nagon kot na nekaj prirojenega, biološkega prav pri stvareh, ki se jih mora ženska naučiti - dojenje, previjanje, nega itd., najbolj naravne dogodke pa opremi s socialnimi pomeni (Mojškerc, 2007).

Kristanova (2005) poudarja, da materinstvo ni le mit, ampak je tudi družbena oz. 
kulturna institucija. V večini kultur se koncepti moškosti in ženskosti namreč definirajo tako, da je ženska prikazana ne le kot drugačna od moškega, ampak je na spoznavni in vrednostni lestvici nižje od moškega. Asimetrija v vrednotenju se utemeljuje v »ženski naravi«, ki služi kot logična podlaga za njihovo izključevanje iz javnega življenja. Domestifikacijo je utrjevalo predvsem prepričanje, da je ženska »naravna« vloga materinstvo. Naturalizacija je eden od načinov marginalizacije, ki služi kot argument za nespremenljivost neke hierarhije.

V slovenskem prostoru je materinstvo pogosto vrednoteno kot poslanstvo in nasploh pomembna vrednota, pogosto pa je tudi način dokazovanja lastne vrednosti. Novorojenček je popolnoma odvisen od kvalitete in potencialov materinega simbiotskega partnerstva. Materin odnos, skrb in naklonjenost, bojazni in omejitve sooblikujejo otrokove izkušnje, na katerih otrok gradi svoj kasnejši model življenja, zahtev, frustracij, izkazovanja ljubezni, pripadnosti in sovražnosti (Selič, 1999). Avtorja raziskav o materinih reprezentacijah in pomenih odnosa z otrokom (Crowell in Feldman, 1991) izhajata iz teorije navezanosti in pravita, da je materina sposobnost koherentnih, pozitivnih in prilagodljivih reprezentacij odnosa $\mathrm{z}$ otrokom povezana z njenimi reprezentacijami lastnih zgodnjih izkušenj navezanosti. Zgodnji odnosi vplivajo na poznejše, oblike navezanosti pa so relativno stabilne in same po sebi težko spremenljive (Gostečnik, 2008a; Kompan Erzar, 2006), pri čemer je pomembno, da je sprememba navezanosti mogoča samo v primeru, ko »ne-varno navezana posameznika med seboj vzpostavita varen odnos (Scarf, 2004). Izvor dinamike regulacije afekta, ki jo otrok razvije ob materi z namenom, da bi se mogel soočiti s stresnimi situacijami, je treba poiskati v zgodnjem odnosu mati-otrok. Mati mora znati sprejeti in nato regulirati otrokova težka čutenja, ki jih sam ne zmore predelati (Gostečnik, 2007; Kompan Erzar, 2003). Pri tem je treba poudariti, da gre pri afektivnem ujemanju med materjo in otrokom za proces dvostranske in vzajemne regulacije (Erzar, 2007), uglaševanje in afektivno sinhronizacijo, kar je ugotovil Stern (1985) z empiričnim in znanstvenim vpogledom $\mathrm{v}$ otrokov razvoj z vidika regulacije njegovih emocij. Ravno sposobnost za modeliranje afektov pa je v središče človekovega doživljanja postavila Bowlbyjeva (1969) teorija navezanosti, s katero je avtor pokazal, da varna navezanost med materjo in otrokom pomeni $\mathrm{v}$ prvi vrsti uspešno regulacijo otrokovih afektivnih in čustvenih stanj (Erzar, 2007). »Materinstvo je še vedno prekrito $z$ vrsto mask, ki prikrivajo temeljno nelagodje moške kulture do materinstva. Odstranjevanje mitičnih tančic z instituta materinstva potrebujemo vsi: tako ženske in matere kot tudi moški in očetje, predvsem pa otroci - bodoči moški in ženske. Brez drugačnega (samo) dojemanja materinskosti kultura ne bo presegla svojega temeljnega nelagodja.« (Kristan, 2005: 253) Tako Havighurst (Rice, 1998; Poljšak Škraban, 2004) kot razvojne naloge zgodnje odraslosti pojmuje: (1)

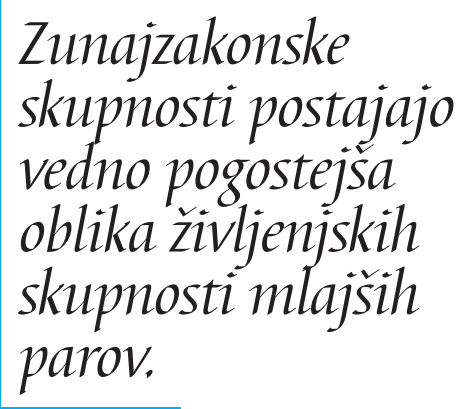
doseganje avtonomije, (2) dograjevanje identitete, (3) razvoj emocionalne stabilnosti, (4) razvoj in utrjevanje kariere, (5) odkrivanje in razvijanje intimnosti, (6) vključevanje v socialne skupine in skupnosti, (7) snovanje in upravljanje ter vzdrževanje domovanja, starševstva ter vzgoje otrok.

V vlogi staršev se mladi odrasli spoprijemajo s prilagajanjem na finančnem, socialnem in čustvenem področju. Družinske odgovornosti se z rojstvom otroka povečajo, partnerska vloga pa se preoblikuje. Različni avtorji v Ameriki in Evropi (npr. Mavnard, 1974; Wicki, 
1999; Zupančič in Filipič, 1995; Marjanovič Umek in Zupančič, 2004) ugotavljajo, da rojstvo prvega otroka in prilagajanje na starševstvo za večino partnerjev pomeni stresno obdobje, v katerem se običajno zmanjša zadovoljstvo s partnerskim odnosom in poveča število partnerskih konfliktov. Kljub temu partnerji v povprečju ostajajo zadovoljni s partnerskim odnosom. Vsakodnevna interakcija z otrokom, skrb zanj, vzgoja in spremljanje njegovega razvoja na eni strani za starše pomenijo vir zadovoljstva, na drugi pa so izvor dodatnih stresov. Starševstvo je za mlade odrasle pomemben razvojni izziv in vpliva na preoblikovanje njihovega pojmovanja o sebi. V njihovo življenje se vključi tudi pojem sebe kot starša. Razvoj starševske vloge sooblikuje interakcija starša z otrokom, ta pa se spreminja s stopnjo otrokovega osebnostnega razvoja in osebnostnega razvoja starša (Marjanovič Umek in Zupančič, 2004).

Petzold (1996) je prepričan, da pojma družine ni lahko opredeliti. Tradicionalno pojmovanje družine vključuje tisto družino, kjer je bil otrok socializiran, in tisto, ki jo posameznik kasneje ustvari sam s partnerjem in otrokom. Družina je tako brez vprašanja zelo pomembna za vsakogar. Spremembe v dojemanju materinske in starševske vloge $\mathrm{v}$ zadnjih desetletjih dovolj prepričljivo kažejo na to, da družin ne moremo opisovati s tradicionalnim konceptom. Nova definicija temelji na intimnosti in medgeneracijskih odnosih, vsebuje zunanje spremembe, ponuja možnosti odločitve za poroko, vključuje enostarševske družine ter družine $\mathrm{z}$ nebiološkimi starši in še bi lahko naštevali. Materinstvo je v konceptu relacijske sistemske teorije pojmovano kot najpomembnejši zgodnji odnos med materjo in otrokom. Ta ni enostranski, temveč vzajemen. Prav odnos mati-otrok je tisti, ki služi kot vzorčni primer odnosa, kot prvi in zadnji dokaz, da odnosi obstajajo in da so pomembni, ugotavlja Kompan Erzar (2009), in nadaljuje, da gre pri materinstvu za edinstveno ujemanje konkretne matere s konkretnim otrokom, ki se razvija $v$ stiku med njima in je za vsak par otrok-mati drugačno.

Diskontinuiteta modernosti $\mathrm{v}$ razmerju do tradicionalnih oblik družbenega reda se kaže v dveh vidikih: (1) v svoji razsežnosti tako, da se globalizira, in (2) v svoji intenzivnosti tako, da sega v same značilnosti intimnega, osebnega vsakdanjega življenja (Giddens, 1995; Švab, 2001). Družina je bila v modernistični perspektivi izenačena $\mathrm{z}$ zasebnostjo oz. je bila zasebnost izenačena s posebno družinsko obliko - nuklearno družino (Švab, 2001). Bolj ko tradicija izgublja pomen in bolj ko se vsakdanje življenje rekonstruira v dialektičnih medsebojnih vplivih lokalnega in globalnega, bolj so posamezniki prisiljeni $\mathrm{v}$ izpogajanje izbir življenjskih stilov v raznolikosti opcij (prav tam). V moderni družbi je ideološka percepcija materinstva zelo odvisna od znanstvenih/medicinskih diskurzov. Ti pa se relativno hitro spreminjajo, kar je v nasprotju z ideološko argumentacijo naravnosti in iz nje izpeljane nespremenljivosti materinstva. Zaradi specifične reproduktivne funkcije pa so ženske ključna vez med naravnim in družbenim (Švab, 2001).

\section{PRIHODNOST MATERINSTVA}

Postmoderna družba ne pomeni radikalnega reza z modernostjo, ampak splet procesov, značilnih za moderno družino, in postmodernih procesov, ki se pojavljajo kot radikalno novi. Tipično postmoderen je fenomen družinske pluralizacije, ki ga moderna družba ne predvideva. Pod tem pojmom razumemo procese, kot so pluralizacija družinskih oblik in z njo povezani pluralizacija življenjskih stilov in življenjskih potekov, spreminjanje družinskih vrednot 
in intradružinska diferenciacija. V postmodernosti se dogaja premik od enopomenske opredelitve družine (nuklearna družina) v smer razširjanja tako družine kot zasebnosti. V postmoderni družbi zakonska zveza izgublja pomen, veča pa se število kohabicij, kar kaže na to, da je ljudem pomembnejše samo družinsko življenje kot pa njegova formalna potrditev. Ob tem opažamo tudi upadanje stopnje rodnosti, kar lahko razumemo kot izraz premišljene odločitve za otroka, tako da mu bomo lahko zagotovili najboljše možnosti za razvoj (Švab, 2001). Povečuje se število reorganiziranih družin, v katerih otroci živijo z očimom ali mačeho, s polsestrami in/ali polbrati. Narašča tudi število enostarševskih družin. V postmodernosti je zaznati tudi zmanjševanje števila družinskih članov, zviševanje starosti ob prvi poroki, naraščanje števila razvez zakona, zviševanje starosti matere ob rojstvu prvega otro$\mathrm{ka}$, naraščanje števila istospolnih družin, veča se delež žensk, ki se zaposlujejo (Švab, 2001). Švabova (2001) ugotavlja, da je materinstvo tisti segment v družini, pri katerem je v postmodernosti zaznati najmanj sprememb. Še vedno je materinstvo ključni dejavnik konstituiranja družine. Materinstvo je torej tista retardirana družinska vloga, ki je s tem, ko je ohranila moderno obliko, sploh omogočila transformacijo in adaptacijo družine pogojem postmoderne (prav tam). Na drugi strani pa družinske spremembe postajajo tudi vse pomembnejši dejavnik pri nadaljnjem načrtovanju izobraževanja staršev (Govekar - Okoliš in Ličen, 2008).

V postmodernosti so se močno spremenili pomeni in pogoji dela in zaposlovanja ter sama narava dela. Pomemben premik v razumevanju dela so naredile feministične teorije s kritiko klasičnega pojmovanja plačanega dela, ki spregleduje pomembnost neplačanega družinskega dela, kot so gospodinjsko, emotivno in odnosno delo. Eden največjih premikov v zvezi z delom oz. zaposlovanjem, ki se je sicer začel množično kazati že v modemi družbi, a je v spremenjenih pogojih tudi temeljna značilnost postmodernosti, je množično zaposlovanje žensk, ki je pomembno vplivalo tudi na družinsko življenje (Pascall, 1997, v Švab, 2001). Prav množično zaposlovanje žensk je fenomen, ki je tako strukturno kot formalno načel moderno nuklearno družino. Od 80. let dalje postaja zaposlitveni vzorec ženske vedno bolj podoben moškemu zaposlitvenemu vzorcu, za katerega je značilna naraščajoča participacija $v$ 30. in 40. letih življenjskega poteka, ko doseže vrhunec, nato pa začne upadati. Ta sprememba v zaposlovanju žensk naj bi bila posledica odlaganja odločitve za materinstvo in odločitve žensk, da svojo kariero nadaljujejo v času, ko so otroci majhni (Švab, 2001).

Veliko avtorjev se sprašuje, ali ima starševstvo in s tem materinstvo prihodnost ter kakšna bo ta, kaj se v prihodnosti lahko spremeni in kakšno bi naj bilo starševstvo $\mathrm{v}$ prihodnje. Ugotavljajo, kaj bi bilo treba spremeniti, da bi bilo starševstvo v prihodnosti uspešno. Brajša (1987) je prepričan, da dilema o tem, ali starševstvo v prihodnosti bo ali ne, sploh ne obstaja. Zatrjuje, da je starševstvo nujno in bo človeku in njegovemu razvoju vedno potrebno. Ob tem se sprašuje, kakšne starše bomo potrebovali v prihodnosti. Pravi, da bo to takšno starševstvo, ki otroku omogoča, da postane odrasel partner svojim staršem in drugim odraslim. Takšno starševstvo zahteva ustrezen tip staršev, to so starši, ki so pripravljeni sprejeti, razvijati in negovati temeljne lastnosti funkcionalnega in uspešnega starševstva. Takšni starši morajo otroka vključevati v širšo skupnost, to pomeni, da ga ne vzgajajo le zase. Otroke je treba usposobiti, da zapustijo starše in družino, da bi oblikovali svojo 
družino in ustvarili lastne partnerske odnose. Izpolnjevanje temeljnih nalog starševstva bo človeštvu vedno potrebno, da bi se lahko ohranili kot ljudje in da bi se kot taki tudi razvili. Sodobna znanost oz. znanost prihodnosti bo morda lahko biološko ustvarila in razvijala ljudi tudi brez starševstva, a starševstva ne bo mogoče nadomestiti z aparati ali genetskim oblikovanjem, če bomo hoteli razviti človeške lastnosti otrok. Za tak razvoj so potrebni živi starši, posebni predstavniki odraslih v otrokovem življenju, in prav zaradi tega je starševstvo nenadomestljivo. Brajša torej zatrjuje, da starševstvo ima svojo prihodnost in bo potrebno tako dolgo, dokler bo živel človeški rod, vendar pa ga je treba narediti boljšega in kakovostnejšega.

S. Kitzinger (1994) na drugi strani je prepričana, da se lahko marsikaj naučimo od družb, ki jih imamo za »nerazvite« in »primitivne«. Medtem ko nam je tehnologija omogočila dokaj visoko življenjsko raven, je industrijska tehnološka kultura materinstvo oropala mnogih njegovih tradicionalnih večplastnih vidikov. V družbi je treba ustvariti takšne razmere, $\mathrm{v}$ katerih lahko ženske dobijo zadovoljivo podporo od drugih in so lahko svobodne v svoji materinski vlogi. Poudarja, da sta gospodinjsko delo in materinstvo tudi politični vprašanji. Izzivata nas k političnim dejanjem, tako na državni kot mednarodni ravni, da bi izbrisali diskriminacijo, po kateri je žensko delo slabše plačano kot moško. Tudi V. Satir (1995) meni, da je treba udejaniti enakopravnost $\mathrm{v}$ medosebnih odnosih. Pravi, da bo s tem dejanjem družina mnogo bolj zdrava in močna. Otroci, ki bodo v domači družini imeli modele za enakopravnost med moškimi in ženskami, bodo mnogo laže odrasli v celovite in zrele ljudi. Za pospešitev razvoja človeštva moramo preoblikovati sedanje duhovne, psihološke, čustvene, družabne, telesne, pravne in razumske zaznave. N. Wolf (2001) opozarja, da bi morali ovreči stereotipe o popolnih materah. Čas je, da uvidimo resnične matere, ki niso vse $»$ sijoče in popolne «, ampak imajo tudi »senčne plati« oz. težave. V prihodnosti bi morali te stereotipe, ki so bili skozi čas in prostor premočno razširjeni, povsem ovreči.

\section{NAMEN IN CILJI RAZISKAVE}

Namen raziskave je bil razširiti dosedanje ugotovitve raziskav o materinstvu. $\mathrm{V}$ empiričnem delu smo raziskovali, kakšne so predstave študentk in študentov o materinstvu, kakšno je njihovo mnenje o trenutnem položaju in vlogi žensk in mater $\mathrm{v}$ povezavi $\mathrm{z}$ materinskim mitom. Cilj raziskave je bil ugotoviti, kakšno prihodnost ima materinstvo, zato smo predpostavili, da je najbolje, da o tem vprašamo bodoče starše.

Ugotoviti smo želeli, ali imajo mladostnice (študentke) drugačno mnenje o materinstvu kot mladostniki (študenti). Odgovore smo primerjali s klasičnimi stereotipi o materinstvu in s statističnimi podatki preteklih let.

Odgovoriti smo želeli na naslednja raziskovalna vprašanja:

1. Ali se med študentkami in študenti pojavljajo razlike glede njihove odločitve, ali bi imeli otroka zunaj zakonske zveze?

2. Ali se med študentkami in študenti pojavljajo razlike $\mathrm{v}$ njihovem mnenju o tradicionalnih vlogah moških in žensk v družini?

3. Ali se med študentkami in študenti pojavljajo razlike $\mathrm{v}$ njihovem pogledu na trditev, da je materinstvo največ, kar lahko ženska doseže v svojem življenju?

4. Ali se med študentkami in študenti pojavljajo razlike $\mathrm{v}$ njihovem mnenju o tem, da lahko zaposlena mati do svojih otrok ustvari enako kakovosten odnos kot nezaposlena? 
5. Ali se med študentkami in študenti pojavljajo razlike v njihovem mnenju o tem, da so ženske v sodobni družbi zatirana skupina?

6. Ali se med študentkami in študenti pojavljajo razlike $\mathrm{v}$ njihovem mnenju glede pomembnosti očetovskega in materinskega dopusta?

7. Ali se med študentkami in študenti pojavljajo razlike v njihovem mnenju o tem, kakšna je prihodnost materinstva?

\section{Raziskovalna metoda}

Uporabili smo deskriptivno in neeksperimentalno kavzalno metodo pedagoškega raziskovanja (Sagadin, 1991).

\section{Opis vzorca}

$\mathrm{V}$ raziskavi je sodelovalo 100 rednih študentov in študentk, od tega 50 moških (50 odstotkov) in 50 žensk (50 odstotkov), s štirih fakultet Univerze v Ljubljani: Fakultete za družbene vede $(\mathrm{N}=25)$, Zdravstvene fakultete $(\mathrm{N}=25)$, Filozofske fakultete $(\mathrm{N}$ $=25)$ in Pedagoške fakultete $(\mathrm{N}=25)$. Povprečna starost anketirancev je bila 25,3 leta $(\mathrm{M}=25,31 ; \mathrm{SD}=2,37)$ in je rangirala od 19 do 28 let. Od tega je bilo 55,6 odstotka anketirancev samskih oz. nikoli poročenih, 16,9 odstotka poročenih, 19,3 odstotka neporočenih v partnerski zvezi, 7,7 odstotka zaročenih in 0,5 odstotka razporočenih oz. ločenih. Vzorec je bil priložnosten.

\section{Opis instrumenta}

Za namen raziskave je bil uporabljen vprašalnik, ki je bil sestavljen posebej za raziskavo. Poleg vprašanj o osebnih podatkih anketirancev (spol, starost, status, partnerska zveza) je vseboval trditve in vprašanja, ki so se nanašali na stereotipe o materinskem mitu ter na mnenje anketirancev o današnjem položaju žensk, vlogi matere in očeta pri vzgoji otrok in v družini, o pogledu študentov in študentk na materinstvo zdaj in v prihodnosti. Če pojasnimo natančneje, je bil vprašalnik sestavljen iz dveh dihotomnih vprašanj, treh deskriptivnih ocenjevalnih lestvic ter iz petih Likertovih lestvic stališč (z naslednjimi stopnjami oz. ponujenimi odgovori: ocena 5 je pomenila »nikakor se ne strinjam «, ocena 4 »v glavnem se ne strinjam «, ocena 3 »mi je vseeno«, ocena $2 » \mathrm{~V}$ glavnem se strinjam $\ll$ in ocena $1 »$ popolnoma se strinjam«).

Študentom smo pred začetkom reševanja tudi predstavili namen ankete in jim podrobneje razložili navodila za odgovarjanje na vprašalnik. Zagotovili smo prostovoljnost in anonimnost sodelovanja ter da bomo podatke uporabili zgolj za potrebe in namen raziskave. Vprašalnik je bil študentom razdeljen v času od 8. do 17. marca 2012.

\section{Postopek obdelave podatkov}

Podatke smo obdelali s programskim paketom SPSS 19,0. Obdelava podatkov je potekala na ravni deskriptivne statistike $\mathrm{z}$ navedbo frekvenc in odstotkov ter srednjih vrednosti (aritmetična sredina). Podatke, ki so vsebovali numerične spremenljivke in so bili omejeni le na dve skupini, smo obdelali s T-preizkusom (Independent-Samples T-test), tiste, ki so imeli več skupin, pa z $\mathrm{x}^{2}$-preizkusom (kjer pogoji zanj niso bili izpolnjeni, smo izračunali Kullbackov preiz$k u s)$. Podatki so prikazani tabelarično.

\section{Rezultati in interpretacija}

Za prvo raziskovalno vprašanje smo postavili naslednjo hipotezo (H1): Med študen$t i$ in študentkami se pojavljajo pomembne razlike $v$ njihovem mnenju o tem, ali bi imeli otroka zunaj zakonske zveze. 
Tabela 1: Mnenje študentov in študentk o tem, ali bi imeli otroka zunaj zakonske zveze

\begin{tabular}{|l|l|l|l|l|l|l|}
\hline \multirow{2}{*}{$\begin{array}{l}\text { Ali bi imeli otroka zunaj } \\
\text { zakonske zveze? }\end{array}$} & \multicolumn{2}{l|}{ ŠTUDENTKE } & \multicolumn{2}{l|}{ ŠTUDENTI } & \multicolumn{2}{l|}{ SKUPAJ } \\
\cline { 2 - 8 } & $f$ & $f(\%)$ & $f$ & $f(\%)$ & $f$ & $f(\%)$ \\
\hline DA & 36 & 72,0 & 39 & 78,0 & 75 & 75,0 \\
\hline NE & 14 & 28,0 & 11 & 22,0 & 25 & 25,0 \\
\hline Skupai & 50 & 100,0 & 50 & 100,0 & 100 & 100,0 \\
\hline
\end{tabular}

Vrednost $\mathrm{x}^{2}$-preizkusa ni statistično pomembna $\left(\mathrm{x}^{2}=0,480, \mathrm{~g}=1, \mathrm{P}=0,488\right)$. Med študenti in študentkami se ne kažejo statistično pomembne razlike glede tega, ali bi imeli otroka zunaj zakonske zveze. Kljub temu pa je iz predstavljenih rezultatov razvidno, da bi zunaj zakonske zveze imelo otroka nekoliko več študentov (78 odstotkov) kot študentk (72 odstotkov). Na podlagi tega smo raziskovalno hipotezo (H1) zavrnili.
Raziskave po Evropi so pokazale, da število otrok, rojenih zunaj zakonske zveze, hitro narašča. Po podatkih Sveta Evrope se je v zahodnoevropskih državah leta 1970 ta delež gibal med 1,4 in 29,8 rojstva na 100 rojstev. Do leta 1997 so se te stopnje močno zvišale in so bile med 8,3 in 65,2 (Recent demographic developments in Europe, 1998, v Švab, 2001). Tudi v Sloveniji dosegamo podobne rezultate.

Tabela 2: Mnenje študentov in študentk o tradicionalnih vlogah moških in žensk v družini ( 1 - popolnoma se strinjam, 5 - nikakor se ne strinjam)

\begin{tabular}{|c|c|c|c|}
\hline & Vrsta anketiranca & Aritmetična sredina & Standardni odklon \\
\hline \multirow{2}{*}{$\begin{array}{l}\text { Najpomembnejša naloga } \\
\text { moškega v zakonu je, da } \\
\text { služi denar. }\end{array}$} & študenti & 3,16 & 1,201 \\
\hline & študentke & 4,00 & 904 \\
\hline \multirow{2}{*}{$\begin{array}{l}\text { Najpomembnejša naloga } \\
\text { ženske v zakonu je, da } \\
\text { skrbi za dom in družino. }\end{array}$} & študenti & 2,92 & 1,226 \\
\hline & študentke & 3,80 & ,904 \\
\hline \multirow{2}{*}{$\begin{array}{l}\text { Materinstvo je največ, } \\
\text { kar lahko ženska doseže } \\
\text { v svojem življenju. }\end{array}$} & študenti & 3,72 & 1,126 \\
\hline & študentke & 3,84 & 1,057 \\
\hline \multirow{2}{*}{$\begin{array}{l}\text { Zaposlena mati lahko do } \\
\text { svojih otrok ustvari prav } \\
\text { tako topel in varen odnos } \\
\text { kot nezaposlena mati. }\end{array}$} & študenti & 2,08 & 1,027 \\
\hline & študentke & 1,40 &, 535 \\
\hline \multirow{2}{*}{$\begin{array}{l}\text { Ženske so v sodobni } \\
\text { družbi kljub nekaterim } \\
\text { spremembam še vedno } \\
\text { zatirana skupina. }\end{array}$} & študenti & 3,58 & ,992 \\
\hline & študentke & 2,64 & ,985 \\
\hline
\end{tabular}


Leta 1956 je bilo zunaj zakonske zveze rojenih 11 odstotkov otrok, približno enak delež se je obdržal vse do začetka 80. let. Nato je začel naraščati. Leta 2006 se je delež otrok, rojenih zunaj zakonske zveze, $\mathrm{v}$ primerjavi z letom 1956, povečal za 4,5-krat. Med vsemi prvorojenci je bilo kar 61 odstotkov otrok rojenih neporočenim materam. Da zunajzakonske skupnosti postajajo vedno pogostejša oblika življenjske skupnosti mlajših parov, lahko posredno sklepamo tudi na podlagi podatkov o drugorojencih: 38 odstotkov teh otrok je bilo rojenih neporočenim staršem (Žnidaršič, 2008).

Za drugo raziskovalno vprašanje smo postavili hipotezo (H2): Med študenti in študentkami se pojavljajo pomembne razlike $v$ njihovem mnenju o tradicionalnih vlogah moških in žensk $v$ družini.

Ob upoštevanju predpostavke o homogenosti varianc $(\mathrm{F}=24,218, \mathrm{P}=0,000)$ je aproksimativni T-preizkus za neodvisne vzorce med študenti in študentkami pokazal statistično pomembne razlike glede tega, ali je najpomembnejša naloga moškega $\mathrm{v}$ zakonu služenje denarja $(\mathrm{t}=-3,951, \mathrm{~g}=901, \mathrm{P}=0,000)$, in glede tega, ali je najpomembnejša naloga ženske $\mathrm{v}$ zakonu skrb za dom in družino $(\mathrm{t}=$ $-4,085, \mathrm{~g}=902, \mathrm{P}=0,000$ ).

Obe trditvi izražata povsem tradicionalen pogled na delitev vlog v družini. Res je, da so včasih denar služili le moški in je bila to njihova glavna naloga $\mathrm{v}$ družini, vendar pa je danes vedno več zaposlenih tudi med ženskami. Tako naj bi se naloga služenja denarja porazdelila med oba starša (Žnidaršič, 2008). Raziskovalno hipotezo (H2), ki pravi, da se mnenja študentov in študentk o tradicionalnih vlogah moških in žensk v družini pomembno razlikujejo, obdržimo. Študenti $(M=3,16)$ se $s$ trditvijo, da je najpomembnejša naloga moškega v zakonu ta, da služi denar, strinjajo bolj kot študentke $(M=4,00)$. Morda študenti še vedno čutijo odgovornost, da morajo za družino finančno poskrbeti, študentke pa se bolj bojujejo za enakopravnost in želijo tudi same prislužiti denar za družino. Tudi s trditvijo, da je najpomembnejša naloga ženske $\mathrm{v}$ zakonu ta, da skrbi za dom in družino, se v večji meri strinjajo študenti $(M=2,92)$ kot pa študentke $(M=3,80)$. Predvidevamo, da je tako zato, ker se nameravajo študentke - glede na to, da študirajo - tudi zaposliti.

Za tretje raziskovalno vprašanje smo postavili hipotezo (H3): Med študenti in študentkami se pojavljajo pomembne razlike glede tega, ali je materinstvo največ, kar lahko ženska doseže v svojem življenju.

Ob upoštevanju predpostavke o homogenosti varianc $(\mathrm{F}=0,001, \mathrm{P}=0,981) \mathrm{T}$-preizkus za neodvisne vzorce med študenti in študentkami ni pokazal statistično pomembnih razlik glede tega, ali je materinstvo največ, kar lahko ženska doseže v svojem življenju ( $\mathrm{t}=$ $-0,550, \mathrm{~g}=98, \mathrm{P}=0,584)$. Zato smo raziskovalno hipotezo (H3) zavrnili. Kljub temu pa je iz predstavljenih rezultatov razvidno, da se anketirani študenti $(\mathrm{M}=3,72) \mathrm{s}$ to trditvijo strinjajo malce bolj kot študentke $(\mathrm{M}=3,84)$. Na splošno pa se tako študentke kot študenti prej ne strinjajo, kot pa strinjajo s tem, da je največ, kar lahko ženska doseže v svojem življenju, materinstvo. Najverjetneje so oboji seznanjeni $\mathrm{z}$ vedno večjim izobraževanjem žensk. Tako je več kot polovica mater v Sloveniji, ki so rodile v letu 2006, imela srednješolsko izobrazbo. Le 13 odstotkov teh mater, ki so se šolale na srednji stopnji, je izobrazbo pridobilo v nižji ali srednji poklicni šoli, večina pa je končala srednjo strokovno ali srednjo splošno šolo. Vsaka tretja mati pa je že pridobila višjo ali visoko izobrazbo (Žnidaršič, 2008). Za ženske je torej v življenju 
pomembno tudi to, da dosežejo višjo izobrazbo, pridobijo službo ter se posvetijo tudi družabnemu življenju, tako da njihova vloga ni omejena zgolj na materinstvo. Študenti in študentke se tega zavedajo, verjetno jim takšen zgled dajejo že starši, pa tudi sami vedo, da študirajo zato, da bodo kasneje dobili službo, tako študenti kot študentke.

V okviru četrtega raziskovalnega vprašanja smo postavili hipotezo (H4): Med študenti in študentkami se pojavljajo pomembne razlike glede tega, ali lahko zaposlena mati do svojih otrok ustvari enako kakovosten odnos kot nezaposlena.

Ob upoštevanju predpostavke o homogenosti varianc $(\mathrm{F}=4,560, \mathrm{P}=0,035)$ je aproksimativni T-preizkus za neodvisne vzorce med študenti in študentkami pokazal statistično pomembne razlike glede tega, ali lahko zaposlena mati do svojih otrok ustvari prav tako topel in varen odnos kot nezaposlena $(\mathrm{t}=$ $\left.4,153, \mathrm{~g}_{2}=733, \mathrm{P}=0,000\right)$. Študentke $(\mathrm{M}=$ 1,40) se s to trditvijo strinjajo bolj kot študenti $(\mathrm{M}=2,08)$. Raziskovalno hipotezo (H4) obdržimo. Ženske si v postmodernih okoliščinah zaposlovanja ne morejo več dovoliti pretrgati kariere zaradi materinstva, saj bi s tem tvegale popolno izključitev iz zaposlovanja.
Teoretiki pa ob tem ugotavljajo, da vedno več ljudi postavlja družinske obveznosti na prvo mesto in zato išče službe pri delodajalcih, ki imajo posluh za usklajevanje družinskih obveznosti in dela (Gilbert, 1993, v Švab, 2001). Matere torej imajo možnost, da kljub delu ustvarijo topel odnos z otroki. Veliko anketiranih študentov se zaveda možnosti, da lahko kljub delu zaposlene matere s svojimi otroki ustvarijo topel in varen odnos. Tako mnenje pa zagovarja statistično pomembno več študentk. Domnevamo, da se najbrž zavedajo, da svojega življenja ne bodo preživljale samo skupaj s svojimi otroki. Ob skrbi za otroke bodo hodile tudi v službo in se vključevale $\mathrm{v}$ družabno okolje, kar pa ne bo nujno vplivalo na kakovost njihovega odnosa $\mathrm{z}$ otrokom.

Pri petem raziskovalnem vprašanju je bila naša hipoteza (H5): Med študenti in študentkami se pojavljajo pomembne razlike $v$ mnenju o položaju žensk $v$ sodobni družbi oz. glede tega, ali so ženske v sodobni družbi zatirana skupina.

Ob upoštevanju predpostavke o homogenosti varianc $(\mathrm{F}=0,001, \mathrm{P}=0,977)$ smo na podlagi T-preizkusa ugotovili statistično pomembne razlike med študenti in študentkami glede tega, ali so ženske v sodobni družbi kljub

Tabela 3: Mnenje študentov in študentk glede pomembnosti očetovskega dopusta ( 1 - je zelo pomemben, 2 je pomemben, 3 - je srednje pomemben, 4 - je nepomemben, 5 - je povsem nepomemben, 6 - ne poznam)

\begin{tabular}{|l|l|l|l|l|l|l|}
\hline \multirow{2}{*}{$\begin{array}{l}\text { Kako pomemben je po } \\
\text { vaši oceni očetovski } \\
\text { dopust? }\end{array}$} & \multicolumn{2}{l|l}{ ŠTUDENTKE } & $\mathrm{f}$ ŠTUENTI & \multicolumn{2}{l|}{ SKUPAJ } \\
\cline { 2 - 8 } & $\mathrm{f}$ & $\mathrm{f}(\%)$ & $\mathrm{f}$ & $\mathrm{f}(\%)$ & $\mathrm{f}$ & $\mathrm{f}(\%)$ \\
\hline Je pomemben & 36 & 72,0 & 41 & 82,0 & 77 & 77,0 \\
\hline Je srednje pomemben & 11 & 22,0 & 8 & 16,0 & 19 & 19,0 \\
\hline Ni pomemben & 2 & 4,0 & 1 & 2,0 & 3 & 3,0 \\
\hline Ne poznam & 1 & 2,0 & 0 & 0 & 1 & 1,0 \\
\hline Skupaj & 50 & 100,0 & 50 & 100,0 & 100 & 100,0 \\
\hline
\end{tabular}


nekaterim spremembam še vedno zatirana skupina $(t=4,756, g=98, P=0,000)$. Studentke $(M=2,64)$ se $s$ to trditvijo strinjajo $\mathrm{v}$ večji meri kot študenti $(\mathrm{M}=3,58)$. Raziskovalno hipotezo (H5) obdržimo. Predvidevamo, da imajo študentke takšno mnenje na podlagi lastnih izkušenj in na podlagi zastopanosti žensk na vodilnih položajih. Študenti pa tega najverjetneje ne zaznavajo kot slabost in se jim zdi takšno stanje samoumevno, ukoreninjeno $\mathrm{v}$ njihovi zavesti, saj so oni $\mathrm{v}$ tem pogledu v prednosti.

Pri šestem raziskovalnem vprašanju smo postavili hipotezo (H6): Med študenti in študentkami se pojavljajo pomembne razlike $v$ njihovem mnenju o pomembnosti očetovskega in porodniškega dopusta.

Vrednost Kullbackovega 2Î-preizkusa ni statistično pomembna $(2 \hat{\mathrm{I}}=2,527, \mathrm{~g}=3, \mathrm{P}=$ $0,470)$. Med študenti in študentkami se ne kažejo statistično pomembne razlike v njihovem mnenju o pomembnosti očetovskega dopusta. Kljub temu pa je iz predstavljenih rezultatov razvidno, da nekoliko več študentov ( 82,0 odstotka) kot študentk (72,0 odstotka) meni, da je očetovski dopust pomemben. mnenju o pomembnosti porodniškega dopusta. Kljub temu pa je iz predstavljenih rezultatov razvidno, da nekoliko več študentk (98 odstotkov) kot študentov (96 odstotkov) meni, da je porodniški dopust pomemben.

Na podlagi podatkov, pridobljenih iz tabel 3 in 4, raziskovalno hipotezo (H6) zavrnemo, saj se tako študenti kot študentke zavedajo, da je očetovski in porodniški dopust pomemben. Kar 77 odstotkov anketirancev namreč meni, da je očetovski dopust pomemben, 97 odstotkov pa, da je pomemben porodniški dopust. Nasprotno le odstotek anketirancev meni, da očetovski dopust ni pomemben, prav nihče pa ne zagovarja mnenja, da ni pomemben porodniški dopust. Ob tem lahko sklepamo, da bo ta dopust tudi v prihodnosti izkoristilo veliko očetov in da se bodo v vzgojo vedno bolj vključevali tudi očeti. Verjetno se to dogaja zato, ker se ženske vedno bolj zaposlujejo in se tako skrb za otroka porazdeljuje na oba starša.

Po podatkih Statističnega urada RS so očeti danes pri skrbi za otroke bolj dejavni, kot so bili njihovi očeti. Očeti v Sloveniji se z otroki ukvarjajo povprečno 12 minut na dan in se po dolžini časa, ki ga porabijo za ukvarjanje z

Tabela 4: Mnenje študentov in študentk o pomembnosti porodniškega dopusta ( 1 - je zelo pomemben, 2 - je pomemben, 3 - je srednje pomemben, 4 - je nepomemben, 5 - je povsem nepomemben, 6 - ne poznam)

\begin{tabular}{|c|c|c|c|c|c|c|}
\hline \multirow{2}{*}{$\begin{array}{l}\text { Kako pomemben je po } \\
\text { vaši oceni porodniški } \\
\text { dopust? }\end{array}$} & \multicolumn{2}{|c|}{ ŠTUDENTKE } & \multicolumn{2}{|c|}{ ŠTUDENTI } & \multicolumn{2}{|c|}{ SKUPAJ } \\
\hline & $f$ & $f(\%)$ & $f$ & $f(\%)$ & $f$ & $f(\%)$ \\
\hline Je pomemben & 49 & 98,0 & 48 & 96,0 & 97 & 97,0 \\
\hline Je srednje pomemben & 1 & 2,0 & 2 & 4,0 & 3 & 3,0 \\
\hline Skupai & 50 & 100,0 & 50 & 100,0 & 100 & 100,0 \\
\hline
\end{tabular}

Vrednost Kullbackovega 2Î-preizkusa ni statistično pomembna $(2 \hat{\mathrm{I}}=0,344, \mathrm{~g}=1, \mathrm{P}=$ 0,554). Med študenti in študentkami se ne kažejo statistično pomembne razlike v njihovem otroki, uvrščajo v spodnjo polovico držav članic EU. Ob popisu prebivalstva leta 2002 je bilo v Sloveniji skoraj 61 odstotkov družin, v katerih so z otroki živeli tudi očeti, slabih pet 
odstotkov pa je bilo družin, v katerih so očeti z otroki živeli sami. Danes, ko so očeti bolj dejavno vključeni $v$ nego in skrb za otroke, kot so bili njihovi očeti (ti so bili predvsem edini hranitelji družine), se vse bolj poudarja skrbstvena vloga sodobnih očetov. Pri tem vidimo vedno večjo pomembnost očetovskega dopusta (Vertot, 2008). Očetovski dopust je sicer dopust, ki traja 90 koledarskih dni, od tega morajo očeti prvih 15 dni izkoristiti v času porodniškega dopusta matere, preostalih 75 dni pa lahko oče izrabi do osmega leta starosti otroka. Za 15 dni očetovskega dopusta država zagotavlja očetovsko nadomestilo, za preostale dni pa zagotavlja plačilo prispevkov za socialno varnost od minimalne plače (Drglin, 2006). V 50. letih 20. stoletja so zaposlene matere v Sloveniji uživale pravico do 105 dni porodniškega dopusta, vendar pa je bilo takrat zaposlenih le 28 odstotkov mater. $\mathrm{V}$ 80. letih pa je bilo med vsemi materami le še 1,7 odstotka kmetovalk; te takrat niso bile upravičene do porodniškega dopusta. Od leta 1982 so bile med upravičenke do tega dopusta vključene zadružne kmetice. Porodniški dopust in dopust za nego in varstvo otroka je trajal osem mesecev oz. eno leto, če je mati izrabila dopust za nego in varstvo s štiriurnim delavnikom. Le 14 odstotkov mater je bilo vzdrževanih, preostalih 86 odstotkov pa je bilo zaposlenih, večinoma $\mathrm{v}$ strokovnih, upravno-administrativnih, pa tudi v industrijskih, trgovskih in storitvenih poklicih (Žnidaršič, 2008). Danes porodniški dopust traja 105 dni in je namenjen pripravi na porod, negi in varstvu otroka takoj po porodu ter zaščiti materinega zdravja ob in po rojstvu otroka. Pravico do porodniškega dopusta ima mati otroka, pod določenimi pogoji pa tudi oče ali druga oseba (Drglin, 2006).

Za zadnje raziskovalno vprašanje smo si postavili hipotezo (H7): Med študenti in študentkami se pojavljajo pomembne razlike $v$ njihovem mnenju o prihodnosti materinstva.

Vrednost Kullbackovega preizkusa je statistično pomembna $(2 \hat{\mathrm{I}}=8,048, \mathrm{~g}=3, \mathrm{P}=$ 0,045). S 4,5-odstotnim tveganjem trdimo, da se med študenti in študentkami pojavljajo

Tabela 5: Mnenje študentov in študentk o prihodnosti materinstva

\begin{tabular}{|l|l|l|l|l|l|l|}
\hline \multirow{2}{*}{$\begin{array}{l}\text { Kakšno prihodnost meni- } \\
\text { te, da ima materinstvo? }\end{array}$} & \multicolumn{2}{l|l|l|}{ ŠTUDENTI } & \multicolumn{2}{l|}{ SKUPAJ } \\
\cline { 2 - 7 } & $f$ & $f(\%)$ & $f$ & $f(\%)$ & $f$ & $f(\%)$ \\
\hline $\begin{array}{l}\text { Matere se bodo boli } \\
\text { posvečale karieri in mani } \\
\text { družini. }\end{array}$ & 19 & 38,0 & 30 & 60,0 & 49 & 49,0 \\
\hline $\begin{array}{l}\text { Matere se bodo mani } \\
\text { posvečale karieri in boli } \\
\text { družini. }\end{array}$ & 3 & 6,0 & 0 & 0 & 3 & 3,0 \\
\hline $\begin{array}{l}\text { Ne bo bistvenih spre- } \\
\text { memb. }\end{array}$ & 27 & 54,0 & 19 & 38,0 & 46 & 46,0 \\
\hline Drugo & 1 & 2,0 & 1 & 2,0 & 2 & 2,0 \\
\hline Skupai & 50 & 100,0 & 50 & 100,0 & 100 & 100,0 \\
\hline
\end{tabular}


pomembne razlike $\mathrm{v}$ mnenju, kakšno prihodnost ima materinstvo. Raziskovalno hipotezo (H7) obdržimo.

Največ študentov (60,0 odstotka) meni, da se bodo matere $\mathrm{v}$ prihodnosti bolj posvečale karieri in manj družini, medtem ko je takšnega mnenja statistično pomembno manj $(38,0$ odstotka) študentk. Menimo, da se študenti zavedajo, da ženske postajajo vedno bolj izobražene, si s tem utrjujejo pot do uspešne kariere in tudi do doslednejšega uveljavljanja pravice do enakopravnosti tako na zasebnem kot službenem področju dela. Morda vidijo v tem tudi vzrok lastne »ogroženosti«, saj je na trgu vedno več delovne sile, s čimer se veča brezposelnost. Če bo na trgu delovne sile vedno več žensk, ki bodo imele enako izobrazbo kot moški, je s tem ogrožena njihova prihodnost. Med študentkami pa jih je največ (54,0 odstotka) prepričanih, da v prihodnosti glede materinstva ne bo sprememb. S tem so najbrž želele potrditi, da se ne bodo nič manj posvečale družini in tudi nič manj karieri.

\section{SKLEP}

Rezultati raziskave so pokazali, da večini bodočih staršev (študentov in študentk) ni pomembno, ali se pred rojstvom otroka poročijo, saj kar 75 odstotkov anketirancev meni, da bi imeli otroka zunaj zakonske zveze. Zakonska zveza izgublja pomembnost. Predvidevamo torej lahko, da se bo v prihodnosti delež tistih, ki imajo otroka zunaj zakonske zveze, še povečeval. S podobnim vprašanjem so se ukvarjali tudi Rener, Švab, Žakelj in Humer (2005), ki so delali raziskavo z očeti, ki so izkoristili očetovski dopust. Ugotovili so, da se z dopustnostjo skupnega življenja brez načrtovane poroke sicer strinja več kot polovica anketiranih, a je na drugi strani tudi četrtina takšnih, ki s trditvijo, da je povsem v redu, če partnerja živita skupaj, ne da bi se nameravala poročiti, ne soglašajo ali sploh ne soglašajo.

Študenti se s trditvijo, da je najpomembnejša naloga moškega v zakonu ta, da služi denar, strinjajo bolj kot študentke. Morda študenti še vedno čutijo odgovornost, da morajo

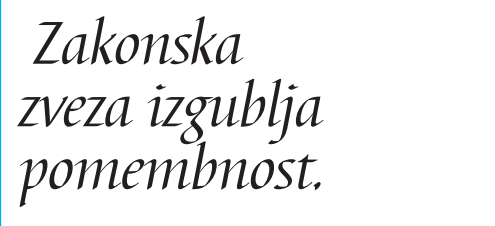
za družino finančno poskrbeti, študentke pa se bojujejo za enakopravnost in želijo tudi same prislužiti denar za družino. Tudi s trditvijo, da je najpomembnejša naloga ženske v zakonu ta, da skrbi za dom in družino, se bolj strinjajo študenti kot študentke. Predvidevamo, da je razlog v tem, da se nameravajo študentke - glede na to, da študirajo - tudi zaposliti in bodo morale skrbeti tudi za druge stvari, ne le za družino. V tem pogledu so študenti torej bolj tradicionalni kot študentke. Kljub temu pa se tako študenti kot študentke bolj nagibajo k odgovoru, da služenje denarja ni najpomembnejša naloga moškega in da skrb za dom in družino ni najpomembnejša naloga ženske v zakonu. Verjetno k temu pripomore tudi dejstvo, da vsi študirajo in najverjetneje želijo s svojo izobrazbo pridobiti službo - tako študenti kot študentke. Opazimo lahko torej težnje po enakopravnosti spolov. Naslednje generacije staršev (vsaj kar se tiče tistih, ki zdaj študirajo) bodo verjetno ustvarjale ženske tudi v drugačnih vlogah, ne le v tistih, ki se vežejo na družino. Tako študentke kot študenti se prej ne strinjajo, kot pa strinjajo s tem, da je največ, kar lahko ženska doseže v svojem življenju, materinstvo.

Med študenti in študentkami ni pomembnih razlik $\mathrm{v}$ njihovem mnenju o pomembnosti očetovskega in porodniškega dopusta. Tako študenti kot študentke se zavedajo, da je očetovski in porodniški dopust pomemben. Statistično pomembne razlike pa smo izsledili pri 
njihovem mnenju o prihodnosti materinstva, kjer največ študentov (60,0 odstotka) meni, da se bodo matere $\mathrm{v}$ prihodnosti bolj posvečale karieri in manj družini, takšno mnenje pa zagovarja manj študentk (38,0 odstotka).

Vloga matere se je do danes zelo spremenila. Vedno več žensk se $v$ današnjih razvitih državah zaposluje in s tem vključuje v širšo družbo, tako da se jim pripisujejo tudi druge vloge in ne le tiste, ki so vezane na družino. Vedno bolj se zavedajo neenakopravnosti spolov in si za boljše razmere tudi prizadevajo - enakopravnost dosegajo z izobraževanjem, zaposlovanjem in vključevanjem $\mathrm{v}$ družabno življenje. Vendar pa jim je kljub temu še vedno pripisana naloga skrbeti za otroke. Počasi se zavedamo potrebe po enakosti spolov in po enakovredni razdelitvi družinskih vlog med moškimi in ženskami. Naša raziskava je pokazala, da se tega bolj zavedajo ženske (študentke) kot pa moški (študenti).

\section{LITERATURA}

Brajša, P. (1987). Očetje, kje ste: Mit in resnica o materinstvu. Ljubljana: Delavska enotnost.

Calvocoressi, P. (1993). Kdo je kdo v Bibliji. Ljubljana: Državna založba Slovenije.

Crowell, J. A., Feldman, S. S. (1991). »Mothers “ working models of attachment relationships and mother and child behavior during separation and reunion«. Developmental psyhology, 4: 597-604.

Drglin, Z., Mihevc Ponikvar, B., Stergar, E., Udrih Lazar, T. (2006). Na poti v materinstvo: vodnik po pravicah nosečnic. Ljubljana: Inštitut za varovanje zdravja.

Erzar, T. (2007). Duševne motnje: psihopatologija $v$ zakonski in družinski terapiji. Celje: Mohorjeva družba.

Govekar - Okoliš, M., Ličen, N. (2008). Poglavja iz andragogike. Ljubljana: Znanstvena založba Filozofske fakultete.
Gostečnik, C. (2007). Relacijska zakonska terapija. Ljubljana: Brat Frančišek in Frančiškanski družinski inštitut.

Gostečnik, C. (2008). Relacijska paradigma in travma. Ljubljana: Brat Frančišek in Frančiškanski družinski inštitut.

Kent, J. (2003). Childhood development. Oxford: University Press.

Kitzinger, S. (1994). Me, matere. Ljubljana: Ganeš.

Kompan Erzar, L. K. (2003). Skrita moč družine. Ljubljana: Brat Frančišek in Frančiškanski družinski inštitut.

Kompan Erzar, K. (2006). Vloga primarnih odnosov in navezanosti v razvoju posameznika. Bogoslovni vestnik, 1: 137-150.

Kompan Erzar, L. K., Poljanec, A. (2009). Rahločutnost do otrok. Ljubljana: Brat Frančišek in Frančiškanski družinski inštitut.

Kristan, Z. (2005). Materinski mit: kultura, psihoanaliza, spolna razlika. Ljubljana: Delta.

Leskošek, V. (2002). Zavrnjena tradicija: Ženske in ženskost v slovenski zgodovini od 1890 do 1940. Ljubljana: Založba / *f.

Marjanovič Umek, L., Zupančič, M. (2004). Razvojna psihologija. Ljubljana: Znanstvenoraziskovalni inštitut Filozofske fakultete.

Mojškerc, N. (2007). »Reprezentacije materinstva v ženskih revijah«. Socialna pedagogika, 3: 361-381.

Oakley, A. (2000). Experiments in knowing: Gender and method in the social sciences. Cambridge: Polity Press.

Petzold, M. (1996). »The psychological definition of ,the family“«. V: Cusinato, M. (ur.). Research on family resources and needs across the world. Milano.

Poljšak - Skraban, O. (2004). Obdobje adolescence in razvoj identitete. Ljubljana: Pedagoška fakulteta.

Praper, P. (1999). Razvojna analitična psihoterapija. Ljubljana: Inštitut za klinično psihologijo.

Rener, T., Švab, A., Žakelj, T. in Humer, Ž. (2005). Perspektive novega očetovstva v Sloveniji: vpliv mehanizma očetovskega dopusta na aktivno očetovanje. Ljubljana: Fakulteta za družbene vede, Univerza v Ljubljani. 
Sagadin, J. (1991). Razprave iz pedagoške metodologije. Ljubljana: Znanstveni inštitut Filozofske fakultete Univerze v Ljubljani.

Satir, V. (1995). Družina za naš čas. Ljubljana: Cankarjeva založba.

Scarf, M. (2004). Secrets, lies, betrayals - the body mind connection. New York: Random House.

Selič, P. (2002). »Pomen psihoanalitične razvojne teorije pri razumevanju dinamike kaznivih dejanj, ki zadevajo adolescente«. Revija za kriminalistiko in kriminologijo, 52: 1-32.

Stern D. N. (1977). The developing child. Cambridge: Harvard University Press.

Šterbenc Erker, D. (2002). Quid lacrimis: Rimska ženska pred obličjem smrti med 2. stol. pr. n. št. in 2. stol. n. št. Ljubljana: Založba /cf.

Švab, A. (2001). Družina: od modernosti k postmodernosti. Ljubljana: Znanstveno in publicistično središče.

Vertot, N. (2008). Očetje v Sloveniji. Statistični urad Republike Slovenije. Dostopno 5. 1. 2009 na http://www.stat.si/novica prikazi.aspx ?id= 1687 .

Wolf, N. (2001). »The motherhood myth «. Times Magazine, 3: 12.

Žmuc Tomori, M. (1988). Klic po očetu. Ljubljana: Cankarjeva založba.

Žnidaršič, T. (2005). Materinski dan. Statistični urad Republike Slovenije. Dostopno 10. 1. 2008 na http://www.stat.si/novica prikazi..aspx?ID=1 525.

Žnidaršič - Žagar, D. (2008). Ženski so pa vzrasle svetlejše dolžnosti nego kuhati in prati: Podoba in pojavnost žensk na Slovenskem. Ljubljana: Pedagoški inštitut. 